УДК 005.1

DOI: https://doi.org/10.37320/2415-3583/21.5

Брінь П.В.

кандидат економічних наук, професор кафедри менеджменту та оподаткування Національний технічний університет «Харківський політехнічний інститут» ORCID: https://orcid.org/0000-0001-7374-3727

Голтвянська Ю.В. магістрант Національний технічний університет «Харківський політехнічний інститут»

\title{
СТРАТЕГІЯ РОЗВИКУ ПІДПРИЕМСТВА: СУТНІСТЬ ТА КЛАСИФІКАЦІЯ
}

У статті розглянуто поняття стратегії як фундаментального складника бізнесу, ї̈ тлумачення та роль у діяльності компанії, досліджено методичні підходи до класифікаиії стратегій розвитку підприємства за роботами вітчизняних та закордонних авторів. На базі результатів аналізу авторами запропоновано додати до загальновизнаних класифікаиійних підходів поділення стратегій розвитку за стадіями життєвого ичклу стратегічної зони господарювання. Запропонована класифікаџія спирається на стадію розвитку бізнесу та передбачає вибір нового підходу до ведення економічної діяльності, тобто зміну стратегії. Використання запропонованого класифікаційного підходу повинно спростити менеджменту підприємств вибір напрямів розвитку та підвищити загальну ефективність господарської діяльності.

Ключові слова: стратегія, бізнес, розвиток підприємства, класифікація стратегій, стадія розвитку бізнесу.

Постановка проблеми. Змінність економічного середовища існування бізнесу створює певні умови невизначеності. Із метою забезпечення стабілізації й посилення стійкості роботи та існування у вибраному сегменті кожен бізнес має виробити і обгрунтувати власну стратегію діяльності. Вибрана стратегія має бути створена за принципом оптимізації витрат, максимізації прибутків та ефективного використання наявних ресурсів, тобто давати максимально можливі віддачі від використання матеріальних, трудових, фінансових ресурсів, регулювати роботу з асортиментом продуктів чи послуг.

Оптимальна стратегія покликана не лише описувати план дій для регулювання роботи підприємства, фірми, організації, а й указувати на шляхи виходу 3 критичних ситуацій, адаптації під зміни ринку.

Аналіз останніх досліджень і публікацій. Вивченням питання стратегій підприємства та їх класифікації займалася велика кількість науковців вітчизняного та зарубіжного походження. Серед публікацій, присвячених стратегії розвитку підприємства, варто відзначити наукові праці таких учених, як I. Ансофф, О. Виханський, О. Гудзь, І. Герчикова, Ю. Погорєлов, С. Клименко, В. Македон, В. Кобєлєв, Ю. Захарченко, М. Портер та ін., але попри чисельність праць, на нашу думку, не знайдено єдиного визначення та класифікації даного поняття, саме тому вибрано цю тему для глибшого аналізу понять і виокремлення загальної спільної думки наявних робіт.

Мета статті полягає у конкретизації поняття «стратегія розвитку» підприємства та систематизації підходів до класифікації стратегій.

Виклад основного матеріалу. Аналіз наукових робіт дає змогу розглянути поняття стратегії з різних точок зору та проаналізувати наявні класифікаційні підходи. Розглядаючи та вивчаючи думки вчених щодо тлумачення поняття «стратегія», можемо зробити висновок, що не існує єдиного визначення, що б повністю характеризувало термін «стратегії» та давало повноту розуміння іiі значення.

Так, В.В. Македон називає стратегією «головний напрям діяльності підприємства, план, який розробляється керівництвом компанії у вигляді стратегічних цілей, завдань і напрямів діяльності підприємства для досягнення нею ефективних показників роботи і бажаного результату» [1]. Тобто поняття «стратегії» ототожнюється 3 планом зі стратегічних цілей, який покликаний привести бізнес до поставленої цілі. С.М. Клименко називає стратегією «довгостроковий, якісно визначений напрям розвитку підприємства, що стосується сфери, засобів і форми його діяльності, системи взаємостосунків усередині підприємства, а також його позиції в навколишньому середовищі, що приводить підприємство до визначених цілей» [2]. На думку автора, стратегія пов'язана 3 довгостроковим плануванням, глобальним напрямом руху бізнесу та його діяльності. Тобто із цих робіт можемо зробити висновок, що стратегія - рушійна сила; те, що має бути створено до початку діяльності і пов'язане 3 фундаментальними цілями діяльності та зародженням бізнесу.

Якщо розглянути поняття «стратегія» $з$ іншого боку, то Ю.С. Погорелов називає стратегію процесом; автор говорить, що «стратегія - безупинний процес, що відбувається за штучно розробленою або природною програмою як зміна станів підприємства, кожен з яких є якісно іншим за попередній, через що у підприємства як у складної системи з'являються нові властивості, якості та характерні риси, розкриваються та можуть бути реалізовані нові можливості» [3]. Тобто він розкриває це поняття 3 погляду постійного процесу, який відбувається за заздалегідь створеним планом.

У роботі В.М. Кобєлєва та Ю.В. Захарченко стратегія - «це постійно коректовані комплекси взаємопов'язаних заходів, спрямованих на досягнення цілей учасників процесу формування стратегії і забезпечення 
ефективного функціонування і розвитку підприємства в короткостроковій і довгостроковій перспективах» [4].

А. Томпсон і А. Стрікленд наполягають, що стратегія - це план підприємства, який починається з формування місії компанії, яка трансформується у цілі, котрі, своєю чергою, повинні підтримуватися завданнями, делегованими конкретним відповідальним особам [5]. Варто додати, що для забезпечення стабільності стратегія підприємства обов'язково повинна спиратися на конкурентну перевагу [6], тобто наш товар (послуга) повинен мати певні характеристики, які $€$ кращими порівняно з конкурентами, при цьому такі конкурентні переваги повинні бути сформовані на базі принципів сталого розвитку [7].

Підсумовуючи, можемо відзначити, що стратегія це план діяльності компанії, який повинен включати як довгострокові, так короткострокові иілі компанії, який побудовано на базі конкурентної переваги та який включає певний перелік завдань, здійснення яких необхідне для досягнення поставлених иілей.

Зазвичай поняття стратегії варто пов'язувати ще й iз ризиком, оскільки будь-яка стратегія зароджується на етапі планування бізнесу та їі подальший розвиток потребує інвестицій, а будь-які грошові вкладення - це завжди ризик, який варто враховувати. Поняття ризику пов'язане $з$ мінливістю економічного середовища, похибками у розрахунках під час планування, неправильного розподілення ресурсів, прорахунку ризиків.

Підсумуємо основні характеристики стратегії розвитку підприємства, що було виявлено у ході дослідження:

1)необхідність інвестиційної підтримки;

2)необхідність урахування ризиків;

3)спрямованість на досягнення результатів;

4)аналіз внутрішніх та зовнішніх чинників;

5)здатність до гнучкості та адаптації до умов.

Розглядаючи вказані характеристики, вибудовується розуміння стратегії як того, що наявне протягом усього життєвого циклу діяльності бізнесу, при цьому, зважаючи за мінливість середовища існування, стратегія адаптується та видозмінюється. Тобто можемо сказати, що в певні періоди діяльності за сприятливих до того умов одна стратегія змінює іншу з урахуванням необхідних змін.

Відповідно, стратегію необхідно певним чином класифікувати залежно від певного параметру. Так, I. Герчикова пропонує розділяти стратегії за набором основних позицій і пріоритетами поставлених цілей [8]. Автор виділяє такі види стратегій:

1)Продуктово-ринкову (стосується технології виробництва продукту чи послуги, їх реалізації).

2) Стратегію управління набором галузей, що передбачає диверсифікацію діяльності.

3) Стратегію поглинання, що розглядає шлях виходу у нові галузі для масштабування.

4) Маркетингову, яка передбачає опис заходів щодо маркетингу діяльності.

5) Конкурентну стратегію, що описує шляхи побудови конкурентоспроможного бізнесу та закріплення позицій у галузі.

6) Стратегію нововведення, яка вказує на шляхи пошуку нових технічних можливостей та розроблення нового продукту, послуги, уведення в експлуатацію нових технологій.

O. I. Гудзь пропонує поділяти стратегії на активні та пасивні, залежно від часу ії впровадження та швидкості реагування на зміни [9]. Автор говорить про активні як про такі, що супроводжують бізнес протягом усієї діяльності та сприяють активному впровадженню будь-яких новинок у галузі чи технологічних див, також вони відповідають за перманентний контроль і регулювання діяльності (збут, виробництво, сервіс тощо).

Про пасивні стратегії у роботі йдеться як про такі, що мають знижений ризик, які концентруються та примноженні існуючої діяльності, іiї збереження; пасивні стратегії не спрямовані на швидке реагування й адаптацію під зміни ринку, за такими зазвичай працюють упевнено, оскільки пасивні стратегії передбачають вибір тих шляхів діяльності, які вже добре проявили себе у конкурентів.

О. Виханський розглядає лише класифікації стратегій зростання [10]. Автор поділяє їх на ті, що відносяться до групи концентрованого зростання (розвиток у вибраній галузі вибраного продукту), інтегрованого зростання (вертикальна та зворотна вертикальна інтеграція) та диверсифікованого зростання.

На базі проведеного аналізу можемо об'єднати згадані думки і запропонувати класифікацію саме за періодом існування бізнесу. Так, ми маємо стратегії, що є фундаментальними чи базисними, тобто такі, що прописуються і розраховуються до створення підприємства, фірми, організації та інвестування в них. Вони зазвичай дають правила діяльності глобального характеру на загальних підставах та допомагають на початку розвитку діяльності. Така стратегія обов'язково потребує корегування в період, коли будуть наявні реакція галузі на нового гравця, дані про лояльність споживачів та партнерів, фінансові обсяги, прибуток тощо.

Наступна група стратегій - стратегії розвитку. Вони розробляються уже безпосередньо в команді, ураховують перші показники реальної діяльності, порівнюють iз плановими, містять адаптовані правила роботи під реальну діяльність та потужність і включають чіткі прогнозування результатів майбутньої діяльності. Зазвичай ця група стратегій є однією з найскладніших, оскільки має вказувати на дії для розвитку діяльності, iї масштабування, збільшення прибуткової частини. Слід відзначити, що для прискорення розвитку та зменшення обсягів необхідних інвестицій компанія може використовувати стратегію аутсорсингу [11].

Ще одна група стратегій - стратегії підтримки, це заключна група стратегій у циклі розвитку, що спрямована на утримання результатів від діяльності та підтримки заданого рівня. Зазвичай такі стратегії вибираються як проміжний варіант між проведенням змін, коли є необхідність зафіксувати рівень прибутку чи діяльності, або ж як постійні у тому разі, коли будь-яке масштабування не розглядається, як і вибір інших стратегій покращення і розвитку діяльності.

I остання група стратегій - стратегії згасання або згортання діяльності. Вони застосовуються на етапі переходу до іншої діяльності, виведення частини діяльності з обороту, галузі або ж на етапі повного згортання діяльності. Для таких стратегій характерні 
Таблиця 1 - Класифікація стратегій розвитку підприсмства

\begin{tabular}{|c|c|c|}
\hline $\begin{array}{l}\text { Стадія життєвого } \\
\text { циклу }\end{array}$ & Вид стратегії & Характеристика \\
\hline \multirow{4}{*}{$\begin{array}{l}\text { Фундаментальні } \\
\text { (стратегії } \\
\text { зародження } \\
\text { бізнесу) }\end{array}$} & Маркетингова & передбачає довгостроковий план, спрямований на посилення конкурентних позицій \\
\hline & Фінансова & $\begin{array}{l}\text { фундаментальна стратегія, що спрямована на створення фінансової політики, } \\
\text { визначення термінів фінансових цілей, аналіз та дослідження фінансового стану }\end{array}$ \\
\hline & Операційна & спрямована на розподіл ресурсів, планування їх використання \\
\hline & Корпоративна & $\begin{array}{l}\text { стратегія, що охоплює у цілому усі напрями діяльності, узагальнює та систематизує } \\
\text { ïх, указує на напрям діяльності всього підприємства }\end{array}$ \\
\hline \multirow{3}{*}{ Розвитку } & Концентрації & $\begin{array}{l}\text { передбачає зосередження ресурсів за певним напрямом, їх розподіл та координацію } \\
\text { у ньому для максимального розвитку цього напряму, досягнення бажаного кінцевого } \\
\text { результату }\end{array}$ \\
\hline & Інтеграції & $\begin{array}{l}\text { передбачає об’єднання кількох напрямів діяльності чи партнерів для досягнення } \\
\text { спільної цілі і збільшення кінцевих результатів діяльності }\end{array}$ \\
\hline & Диверсифікації & $\begin{array}{l}\text { розроблення та просування кількох не пов’язаних між собою видів продукції чи } \\
\text { послуг, розширення спектру діяльності }\end{array}$ \\
\hline \multirow[b]{2}{*}{ Підтримки } & Модифікації & $\begin{array}{l}\text { передбачає планування розширення цільової аудиторії у наявних товарів та послуг. } \\
\text { Стратегія передбачає розроблення заходів для збереження цінності продукції }\end{array}$ \\
\hline & $\begin{array}{l}\text { Підтримки } \\
\text { виробничого } \\
\text { потенціалу }\end{array}$ & довгостроковий план підтримки конкурентоспроможного виробництва \\
\hline \multirow{3}{*}{ Згасання } & Ліквідації & $\begin{array}{l}\text { систематизований план, що передбачає діяльність, спрямовану на припинення } \\
\text { діяльності бізнесу та переорієнтування наявних ресурсів до іншої діяльності }\end{array}$ \\
\hline & Відновлення & $\begin{array}{l}\text { передбачає комплексну програму дій щодо виявлення та ліквідації «слабких місць» } \\
\text { діяльності підприємства для відновлення після кризового періоду }\end{array}$ \\
\hline & Відділення & $\begin{array}{l}\text { стратегія, що спрямована на поступову ліквідацію не всього бізнесу, а його } \\
\text { неприбуткової (збиткової) частини для підвищення ефективності використання } \\
\text { ресурсів, їх обороту }\end{array}$ \\
\hline
\end{tabular}

збереження вартісного значення ресурсів, оптимізація процесу розірвання відносин із галуззю та можливі виходи. Роль таких стратегій надзвичайно важлива, оскільки від них залежать ефективність виведення ресурсів із діяльності та їх подальше розміщення, ефективність роботи з ними. Слід відзначити, що під час розроблення даних стратегії можливе використання принципів реінжинірингу [12].

Детальніше групи стратегій розглянемо в табл. 1.

Висновки. Стратегія розвитку підприємства - фундаментальний складник побудови та управління біз- несом. Від іiі правильного і вчасного вибору залежать ефективність діяльності всього бізнесу, його прибутковість та конкурентоспроможність. Нині існує кілька стратегічних моделей поведінки, які вчені класифікують за різними параметрами, акцентуючи увагу на найважливішій, на їхню думку, характеристиці. У статті висунуто пропозицію класифікації стратегій за часовим етапом розвитку підприємства та її цільовим застосуванням. Так, виокремлено стратегії, що відносяться до фундаментальних, стратегій розвитку, підтримки та згортання бізнесу.

\section{Список використаних джерел:}

1. Македон В.В. Розробка стратегії розвитку промислового підприємства. Теоретичні і практичні аспекти економіки та інтелектуальної власності. 2013. Вип. 1(1). С. 369-373.

2. Клименко С.М. Формування стратегії розвитку підприємства з урахуванням ризиків. Бізнес Інформ. 2013. № 8. С. $343-347$.

3. Погорелов Ю.С. Способи розвитку підприємства: умови та результативність використання. Економічний журнал Одеського політехнічного університету. 2017. № 1. С. 76-84.

4. Кобєлєв В.М., Захарченко Ю.В. Теоретичні та методологічні основи формування стратегії розвитку підприємства. Вісник економіки транспорту і промисловості. 2013. Вип. 42. С. 297-303.

5. Thompson A. et al. Crafting \& executing strategy. The quest for competitive advantage: Concepts and cases. McGraw-Hill Education. 2013.

6. Брінь П.В., Прокоп М.В., Нехме М.Н. Динамічне оцінювання конкурентоспроможності підприємства. Науковий вісник Ужгородського начіонального університету. Серія «Міжнародні економічні відносини $і$ світове господарство». 2019. Вип. Ч. 1. С. $62-68$

7. Brin, P., Nehme, M. Sustainable Development in Emerging Economy: using the analytical hierarchy process for Corporate Social Responsibility decision making. Journal of Information Technology Management. 2021. №13 (Special Issue: Role of ICT in Advancing Business and Management)). P. 159-174. DOI: 10.22059/jitm.2021.80744.

8. Герчикова И.Н. Менеджмент. Москва : Банки и биржи, ЮНИТИ, 1995. 480 с.

9. Гудзь О.І. Стратегія розвитку підприємства: сутність та класифікація. Економічний журнал Мукачівського державного університету. 2018. № 18. С. 346-352.

10. Виханский О.С., Наумов А.И. Менеджмент : учебник. Москва : Гардарики, 2003. 528 с.

11. Брінь П.В., Прохоренко О.В. Багаторівнева класифікація відносин аутсорсингу. Економіка і фінанси. 2013. № 12. С. 78-85.

12. Брінь П.В. Застосування принципів реінжинірингу при розробці санаційної стратегії підприємств промисловості. Наукові праці ДонНТУ. Серія економічна. 2005. Вип. 89-2. С. 148-154. 


\section{References:}

1. Makedon V.V. (2013) Rozrobka stratehii rozvytku promyslovoho pidpryiemstva [Development of an industrial enterprise development strategy]. Teoretychni i praktychni aspekty ekonomiky ta intelektualnoi vlasnosti [Theoretical and practical aspects of economics and intellectual property], 1(1), 369-373.

2. Klymenko S.M. (2013) Formuvannia stratehii rozvytku pidpryiemstva z urakhuvanniam ryzykiv [Formation of risk development strategy of the enterprise]. Biznes Inform [Business Inform], 8, 343-347.

3. Pohorelov Y.S. (2017) Sposoby rozvytku pidpryiemstva: umovy ta rezultatyvnist vykorystannia [Ways of enterprise development: conditions and effectiveness of use]. Ekonomichnyi zhurnal Odeskoho politekhnichnoho universytetu [Economic Journal of Odessa Polytechnic University], 1, 76-84.

4. Kobieliev V.M., \& Zakharchenko Yu.V. (2013) Teoretychni ta metodolohichni osnovy formuvannia stratehii rozvytku pidpryiemstva [Theoretical and methodological foundations of enterprise development strategy formation]. Visnyk ekonomiky transportu i promyslovosti [Bulletin of Transport Economics and Industry], 42, 297-303.

5. Thompson A. et al. (2013) Crafting \& executing strategy. The quest for competitive advantage: Concepts and cases. McGrawHill Education.

6. Brin P. V., Prokop M. V., \& Nehme M. N. (2019) Dynamichne otsiniuvannia konkurentospromozhnosti pidpryiemstva [Dynamic assessment of enterprise competitiveness]. Naukovyi visnyk Uzhhorodskoho natsonalnoho universytetu. Seriia Mizhnarodni ekonomichni vidnosyny i svitove hospodarstvo [Scientific Bulletin of Uzhhorod National University. International Economic Relations and the World Economy Series], 28 (1), 62-68.

7. Brin, P., \& Nehme, M. (2021). Sustainable Development in Emerging Economy: using the analytical hierarchy process for Corporate Social Responsibility decision making. Journal of Information Technology Management, 13 (Special Issue: Role of ICT in Advancing Business and Management)), 159-174.

8. Herchykova Y. N. (1995) Menedzhment [Management]. Moskow: Banky y byrzhy, YuNYTY. 480 p. (in Russian)

9. Hudz O.I. (2018) Stratehiia rozvytku pidpryiemstva: sutnist ta klasyfikatsiia [Enterprise development strategy: essence and classification]. Ekonomichnyi zhurnal Mukachivskoho derzhavnoho universytetu [Economic Journal of Mukachevo State University], $18,346-352$.

10. Vykhanskyi O.S., Naumov A. Y. (2003) Menedzhment. [Management]. Moskow: Hardaryky. 528 p. (in Russian)

11. Brin P.V., \& Prokhorenko O.V. (2013) Bahatorivneva klasyfikatsiia vidnosyn autsorsynhu [Multilevel classification of outsourcing relationships]. Ekonomika i finansy [Economics and finance], 12, 78-85.

12. Brin P.V. (2005) Zastosuvannia pryntsypiv reinzhynirynhu pry rozrobtsi sanatsiinoi stratehii pidpryiemstv promyslovosti [Application of reengineering principles in the development of remediation strategy of industrial enterprises]. Naukovi pratsi DonNTU [Scientific works of DonNTU], 89-2, 148-154.

Brin Pavlo, Holtvyanska Yuliia

National Technical University «Kharkiv PolytechnicInstitute»

\section{ENTERPRISE DEVELOPMENT STRATEGY: ESSENCE AND CLASSIFICATION}

The article considers the concept of strategy as a fundamental component of business, its interpretation and role in the company; explores methodological approaches to the classification of enterprise development strategies by papers of many native and foreign authors. The enterprise strategy is considered as one of the main concepts in strategic management. Various scholars have proposed many definitions of the term "strategy". From these definitions it has been concluded that strategy is a component of strategic management that allows the company to achieve clearly defined objectives, to ensure competitiveness in the market, to ensure the state of the company so that it can operate successfully in difficult market conditions.Every organization must have clearly defined goals in order to ensure stable work in the future. This requires managers to understand the essence of strategy, use techniques and methods of strategic management, development of strategic plans. Hence, the strategy must change and adapt to changing conditions of both external and internal environments of the company. The authors have defined that the strategy is a plan of the company, which should include both long-term and short-term goals of the company, which is based on competitive advantage, and which includes a list of tasks that must be attained to achieve these goals. The enterprise development strategy is a set of methods and processes invested in achieving goals and objectives. The formation of enterprise development strategy plays an important role in adapting the business to the ever-changing external and internal market environment. Based on the results of the analysis, the authors propose to add to the generally accepted classification approaches the division of development strategies according to the stages of the life cycle of the strategic management area. The proposed classification is based on the stage of business development and involves the choice of a new approach to economic activity. Using of the proposed classification approach should simplify for the management of enterprises the choice among different ways of development and increase the overall efficiency of economic activity.

Key words: strategy, business, enterprise development, classification of strategies.

JEL classification: G32, O32 